\title{
PCR detection of Ehrlichia ruminantium and Babesia bigemina in cattle from Kwara State, Nigeria: unexpected absence of infection
}

\author{
Elkie Hector ${ }^{1}$ (D) $\cdot$ Nusirat Elelu ${ }^{1,2} \cdot$ Joana Ferrolho $^{3} \cdot$ Joana Couto $^{3} \cdot$ Gustavo Sanches $^{3} \cdot$ Sandra Antunes $^{3}$. \\ Ana Domingos ${ }^{3} \cdot$ Mark Eisler $^{1}$
}

Received: 4 March 2018 / Accepted: 4 January 2019 / Published online: 17 January 2019

(C) The Author(s) 2019

\begin{abstract}
Ticks and tick-borne diseases (TBDs) continue to pose an insidious and ever-present threat to livestock and livelihoods across the globe. Two of the most significant TBDs of cattle in Africa are heartwater and babesioisis, caused by Ehrlichia ruminantium and Babesia bigemina respectively. Both pathogens are endemic in Nigeria. However, to date, little data has been published regarding the number of cattle infected. In this study, blood samples were collected from cattle of the Kwara State, north-central Nigeria. Probe-based quantitative PCR (qPCR) and semi-nested PCR were used to investigate the presence of both pathogens, respectively. Our study found all samples $(n=157)$ to be surprisingly negative for both B. bigemina and E. ruminantium. These results contribute new information on the current burden of these two pathogens in Kwara State and may be helpful in informing more effective targeting of control strategies in Nigeria.
\end{abstract}

Keywords Ehrlichia ruminantium · Babesia bigemina $\cdot$ Tick-borne diseases $\cdot$ Semi-nested PCR $\cdot$ qPCR $\cdot$ Nigeria

\section{Introduction}

Two of the most significant tick-borne diseases (TBDs) of cattle in Africa are heartwater and babesiosis (Jongejan and Uilenberg 2004). Heartwater is a lethal bacterial disease, caused by the intracellular rickettsia Ehrlichia ruminantium, affecting ruminants and wild animals throughout sub Saharan Africa (OIE 2009). Transmission is largely thought to occur by ticks of the genus Amblyoma (Provost and Bezuidenhout
1987). The clinical signs include sudden fever, anorexia, respiratory failure and sudden death with mortality rates as high as $80 \%$ (Camus et al. 1996). Native cattle breeds living in endemic areas display varying levels of resistance and susceptibility; however, highly productive (European) breeds and their crosses suffer high morbidity and mortality rates (Camus et al. 1996). Bovine babesiosis is caused by a protozoan of the genus Babesia that parasitises host erythrocytes. It is estimated that over half a billion cattle may be at risk of

Section Editor: Leonhard Schnittger

Elkie Hector

eh14555.2014@my.bristol.ac.uk

Nusirat Elelu

nusyelelu@yahoo.com

Joana Ferrolho

joana.ferrolho@ihmt.unl.pt

Joana Couto

joana.couto@ihmt.unl.pt

Gustavo Sanches

gustavo.seron@ihmt.unl.pt

Sandra Antunes

santunes@ihmt.unl.pt

\author{
Ana Domingos \\ adomingos@ihmt.unl.pt \\ Mark Eisler \\ mark.eisler@bristol.ac.uk \\ 1 Bristol Veterinary School, University of Bristol, Langford, \\ Bristol BS40 5DU, UK \\ 2 Faculty of Veterinary Medicine, University of Ilorin, Ilorin, Kwara \\ State, Nigeria \\ 3 Global Health and Tropical Medicine-Instituto de Higiene e \\ Medicina Tropical, Rua de Junqueira 100, \\ 1349-008 Lisbon, Portugal
}


infection by bovine babesiosis worldwide (Kim et al. 2007). One of the most important Babesia species reported in Africa is B. bigemina (Young et al. 1988), with infected animals displaying common clinical signs of fever, inappetence, jaundice, weight loss, haemoglobinemia and haemoglobinuria (Young et al. 1988; Susan and Asa 1998; Bock et al. 2004). Transmission in cattle occurs principally by ticks of the genus Rhipicephalus (OIE 2013). To date, few studies have investigated the prevalence of $B$. bigemina and E. ruminantium in Nigeria. Of those that have, only a small number have employed molecular methods, largely relying instead on serological techniques with the disadvantage of antigenic crossreactions (Akinboade and Dipeolu 1984; Ajayi and Dipeolu 1986; Ogunsusi 1989; Kelly et al. 1994; Papadopoulos et al. 1996; Savadye et al. 1998). The aim of this study was to provide more information regarding the presence of $B$. bigemina and E. ruminantium in cattle blood samples obtained from a region of Kwara State, Nigeria, using probe-based quantitative real-time PCR (qPCR) and a semi-nested PCR. Our results will contribute toward improving disease control strategies, enabling the development of sustainable and productive livestock farming systems, ensuring food security and ultimately supporting economic growth.

\section{Materials and methods}

\section{Study population}

A total of 253 bovine blood samples collected from 11 cattleproducing villages across the Edu Local Government Area (LGA) in Kwara State, Nigeria, were included in the study (Table 1). The animals were randomly selected and clinically healthy at sampling. The procedures for sample selection, collection, extraction and storage can be found in Elelu et al. (2016). From the 253 samples collected, 96 were excluded

\begin{tabular}{llll}
$\begin{array}{llll}\text { Table 1 Villages across } \\
\text { the Edu Local }\end{array}$ & Village & Latitude & Longitude \\
\cline { 2 - 3 } $\begin{array}{l}\text { Government Area } \\
\text { (LGA) in Kwara State, }\end{array}$ & Bacita & 9.03716 & 4.57834 \\
$\begin{array}{l}\text { Nigeria, which were in- } \\
\text { cluded in the study and }\end{array}$ & Belle & 9.10084 & 4.56429 \\
their geographic loca- & Bokungi & 8.50345 & 5.01229 \\
tions (decimal degrees) & Fanagun & 9.08517 & 4.57767 \\
& Fedudangi & 8.51867 & 5.02557 \\
& Gonandogo & 9.04780 & 4.57341 \\
& Mokwagi & 9.03135 & 4.55922 \\
& Ndabata & 8.57171 & 5.09441 \\
& Ndachewoye & 9.04550 & 4.54668 \\
& Tshonga farm & 8.57522 & 5.08022 \\
& Yelwa & 9.08366 & 4.56211 \\
\hline
\end{tabular}

from the current study due to a lack of sufficient biological material.

\section{Pathogen detection and data analysis}

A PCR that amplifies a 437-bp fragment of the GAPDH gene was carried out to confirm DNA integrity and the absence of PCR inhibitors as previously described (Birkenheuer et al. 2003). All the samples used in this study were positive for the correct amplicon. A probe-based quantitative qPCR assay with a sensitivity of $100 \%$ was used to detect and amplify a fragment of the B. bigemina $18 \mathrm{~S}$ rRNA gene as previously described (Kim et al. 2007). Briefly, $20 \mu \mathrm{l}$ reactions were prepared with $10 \mu \mathrm{l}$ of SensiFAST ${ }^{\text {TM }}$ Probe Low-Rox mix (Bioline, London, UK), $100 \mathrm{nM}$ of probe (StabVida, Lisbon, Portugal), $400 \mathrm{nM}$ of reverse and forward primers (StabVida), $2 \mu \mathrm{l}$ of DNA template and nuclease-free water up to the final volume. Triplicate reactions were set up for each sample and were loaded into 96-well plates (VWR, Pennsylvania, USA). Thermal cycling conditions were as follows: one stage at $95{ }^{\circ} \mathrm{C}$ for $10 \mathrm{~min}$, followed by 45 cycles of $95^{\circ} \mathrm{C}$ for $20 \mathrm{~s}$ and $55^{\circ} \mathrm{C}$ for $1 \mathrm{~min}$. An Applied Biosystems 7500 Fast thermal cycler was used (ThermoFisher Scientific, Waltham, MA). Positive controls were prepared with the B. bigemina Israel strain, and negative (no template) controls with nuclease-free water. PCR efficiency was determined using sequence-specific fivefold serial dilution standard curves prepared with DNA from the positive control.

A semi-nested hot-start PCR with a sensitivity of $90 \%$ was also conducted to determine the presence of $B$. bigemina as previously reported by Martins et al. (2008), to amplify $614 \mathrm{bp}$ and $275 \mathrm{bp}$ fragments of a target region of the aspartic proteinase babesipsin gene. PCR reactions were prepared with $5 \mu$ of Supreme NZYTaq 2X Green Master Mix (NZYTech, Lisbon, Portugal), $0.5 \mu \mathrm{M}$ of primers BigBAF1 and BigBAF2, $2 \mu \mathrm{l}$ of nuclease-free water and $2 \mu \mathrm{l}$ of DNA template. Negative controls were prepared with no template and positive controls with $B$. bigemina DNA. Samples were loaded into 96-well plates (VWR) and the thermal cycling conditions used were the same as previously described by Martins et al. (2008) in a Bioer Gene Pro thermocycler (Hangzhou Bioer Technology Co., Ltd., China). PCR products from the first reaction were used for a second reaction using the primers BigBAF1 and BigBAR2 and under the same conditions as above. PCR products were separated on a $1.2 \%$ agarose (NZYTech) gel $(w / v)$ in $0.5 \times$ TBE buffer $(20 \mathrm{mM}$ Tris, $20 \mathrm{mM}$ boric acid, $0.5 \mathrm{mM}$ EDTA, $\mathrm{pH}$ 7.2) stained with SybrSafe $^{\mathrm{TM}}$ (Invitrogen, CA, USA) and examined by UV transillumination. The NZYDNA Ladder VIII DNA molecular weight marker (NZYTech) was used to confirm the size of the products.

The presence of $E$. ruminantium was investigated with a probe-based qPCR as described by Steyn et al. (2008) to 
amplify a fragment containing two overlapping genes, $r n c$ and cta $G$, within the $P C S 20$ gene region. This assay has sensitivity to detect PCS20 down to a dilution of $10^{-8}$ (7 PCS20 copies/ $\mu$ l) (Steyn et al. 2008). Briefly, $10 \mu \mathrm{l}$ reactions were prepared with $5 \mu$ of Grisp Xpert Fast Probe mix (Grisp, Porto, Portugal), $0.5 \mu \mathrm{M}$ of each primer (StabVida), $0.4 \mu \mathrm{M}$ of probe (StabVida), $1 \mu$ l of DNA template and nuclease-free water up to the final volume. Negative controls were prepared without DNA template, and positive controls with DNA extracted from E. ruminantium-infected tick cells. Triplicate reactions for each sample were loaded into 96-well plates (VWR) and run in a CFX Connect TM® Real-Time PCR Detection System with the thermal cycling conditions described previously (Bio-Rad, CA, USA). A standard curve was constructed with fivefold serial dilutions of the positive control DNA to determine reaction efficiency. Real-time PCR data was analysed using Bio-Rad CFX manager software version 3.1 (Bio-Rad) and the Applied Biosystems 7500 Fast 2.0.6 Software (ThermoFisher Scientific). Based on the standard curves, the threshold detection levels at each quantification cycle were set at 19.00 and 0.012 for E. ruminantium and $B$. bigemina, respectively. Samples requiring more than 36 quantification cycles $(\mathrm{Cq})$ for detection above these thresholds were considered negative for the presence of pathogen. Confidence intervals (CI) for the proportion of samples which were found positive were calculated using the Wilson score (Brown et al. 2001).

\section{Results and discussion}

A total of 157 blood samples collected from White Fulani $(97.5 \%)$ and Jersey $(2.5 \%)$ bovines of 11 cattle-producing villages in Edu LGA were tested for presence of $E$. ruminantium and $B$. bigemina. A probe-based qPCR targeting a fragment of the $18 S$ rRNA gene was conducted to screen the presence of $B$. bigemina in the blood samples. No samples were found to be positive according to the defined threshold. A few studies have reported that in this region, the frequency of $B$. bigemina should be higher than that found in this study (Abdullahi et al. 2014; Olabode et al. 2014; Lorusso et al. 2016). In view of this, a semi-nested hot-start PCR targeting the putative aspartic proteinase babesipsin gene of $B$. bigemina was performed to confirm the result. Again all samples were found to be negative. Our finding of no positive animals does not agree with the reported data on B. bigemina prevalence across Africa, which is recorded to be as high as $90 \%$ in cattle (Martins et al. 2008). The detection of pathogens in ticks frequently does not correlate directly with their presence in their hosts; indeed, a low prevalence in ticks could be associated with a very high prevalence in cattle (Tay et al. 2014). Ogo et al. (2012) analysed 218 ticks collected in north-central Nigeria, a similar geographic area to this study, and reported the presence of $B$. bigemina in $1.3 \%$ of the specimens. A possible explanation for low detection rates in ticks and hosts is the existence of a second parasite co-infection (Purnell et al. 1977; Friedhoff 1990; Kocan 1995; Zintl et al. 2003). Elelu et al. (2016) sampled the same individuals included in this study and found $75.9 \%$ to be positive for Anaplasma marginale. Within the definitive host, it has been suggested, through experimental infection of splenectomised calves, that concurrent infection with Anaplasma is able to supress Babesia colonisation (Purnell et al. 1977; Zintl et al. 2003). However, further studies of the interaction mechanisms would be beneficial, and certainly, a higher number of samples would give a more accurate idea about the presence of $B$. bigemina in this area of Nigeria.

Ehrlichia ruminantium infection has been reported to affect $61 \%$ of the cattle in West Africa (Koney et al. 2004) and is considered to be endemic to Nigeria (Leeflang 1977; Leeflang and Llemobade 1977). Despite these reports of high morbidity, all the samples in this study were found to be negative for the pathogen. A similarly low occurrence of $1.1 \%$ was reported by Lorusso et al. (2016) in 704 indigenous cattle tested in the Plateau State, Nigeria. Findings of low prevalence are often attributed to the biology of E. ruminantium infection. Initial disease is associated with a febrile period during which high concentrations of microorganisms are found in the blood. Animals that survive often become asymptomatic carriers, releasing E. ruminantium just periodically into the circulation (Andrew and Norval 1989). The resulting low levels of pathogen in host blood samples has proven problematic for pathogen detection, and thus carrier animals can appear negative when tested. Although the qPCR protocol used in this study has been reported to be highly sensitive and to identify carriers in the field (Steyn et al. 2008), it is possible that circulating $E$. ruminantium levels in carrier animals included in this study were too low for detection. A different explanation is that reported prevalence of E. ruminantium is artificially high. Serological techniques have previously been popular for its detection but are now known to lack accuracy (Kelly et al. 1994; Papadopoulos et al. 1996; Savadye et al. 1998).

\section{Conclusion}

The incidence of tick-borne diseases is increasing globally, challenging our approach toward diagnosis, treatment and control options. Heartwater and babesiosis are generally considered to be endemic and two of the most important diseases that affect cattle in Nigeria, not only directly affecting animal health negatively, but also impacting on the local economy. Our study has shown no detection of $B$. bigemina nor $E$. ruminantium in any of the blood samples tested. These results disagree with the current accepted presence of these pathogens within Nigeria. As such, further investigations with an 
increased number of samples and over a wider geographic area within central Nigeria are warranted to confirm these findings. Better understanding of ticks and TBDs circulating amongst Nigerian cattle will be vital to improve animal health and consequently livelihoods of local populations.

Acknowledgements We thank Dr Leslie Bell-Sakyi of the University of Liverpool who kindly provided E. ruminantium DNA and Dr Varda Shkap of the Kimron Veterinary Institute, Israel, for the B. bigemina control. We also express our sincere gratitude to the staff of the Department of Veterinary Services, Kwara State Ministry of Agriculture, for providing field support, and all the farmers in Kwara State who participated in the research.

Funding information The authors would like to acknowledge the University of Ilorin and the University of Bristol for funding this project.

\section{Compliance with ethical standards}

Ethical approval All applicable international, national and institutional guidelines for the care and use of animals were followed. This article does not contain any studies with human participants performed by any of the authors.

Conflict of interest The authors declare that they have no competing interests.

Open Access This article is distributed under the terms of the Creative Commons Attribution 4.0 International License (http:// creativecommons.org/licenses/by/4.0/), which permits unrestricted use, distribution, and reproduction in any medium, provided you give appropriate credit to the original author(s) and the source, provide a link to the Creative Commons license, and indicate if changes were made.

Publisher's Note Springer Nature remains neutral with regard to jurisdictional claims in published maps and institutional affiliations.

\section{References}

Abdullahi SM, Abubakar SM, Dris YI, Alhaji MA, Kabir I (2014) Survey of haemoparasitic infections in dairy cattle (Friesian breeds) at Nagari integrated dairy farms, Gauta-Nike village, Keffilocal government area, Nasarawa state, North Central State of Nigeria. Sci J Vet Adv 3:77-82

Ajayi SA, Dipeolu OO (1986) Prevalence of Anaplasma marginale, Babesia bigemina and B. bovis in Nigerian cattle using serological methods. Vet Parasitol 22:147-149

Akinboade OA, Dipeolu OO (1984) Comparison of blood smear and indirect fluorescent antibody techniques in detection of haemoparasite infections in trade cattle in Nigeria. Vet Parasitol 14:95-104

Andrew HR, Norval RA (1989) The carrier status of sheep, cattle and African buffalo recovered from heartwater. Vet Parasitol 34:261266

Birkenheuer AJ, Levy MG, Breitschwerdt EB (2003) Development and evaluation of a seminested PCR for detection and differentiation of Babesia gibsoni (Asian genotype) and B-canis DNA in canine blood samples. J Clin Microbiol 41:4172-4177

Bock R, Jackson L, Vos AD, Jorgensen W (2004) Babesiosis of cattle. (Special issue: Ticks: biology, disease and control). Parasitology 129:247-269
Brown L, Cai T, Dasgupta A (2001) Interval estimation for a binomial proportion. Stat Sci 16:101-133. https://doi.org/10.1214/ss/ 1009213286

Camus E, Barre N, Martinez D, Uilenberg G (1996) Heartwater (cowdriosis), a review. Heartwater, 2, Office International des Epizooties, Paris

Elelu N, Ferrolho J, Couto J, Domingos A, Eisler MC (2016) Molecular diagnosis of the tick-borne pathogen Anaplasma marginale in cattle blood samples from Nigeria using qPCR. Exp Appl Acarol 70:501510

Friedhoff KT (1990) Interaction between parasite and tick vector. Int J Parasitol 20:525-535

Jongejan F, Uilenberg G (2004) The global importance of ticks. (Special issue: Ticks: biology, disease and control). Parasitology 129:3-14

Kelly PJ, Matthewman LA, Mahan SM, Semu S, Peter T, Mason PR, Brouqui P, Raoult D (1994) Serological evidence for antigenic relationships between Ehrlichia canis and Cowdria ruminantium. Res Vet Sci 56:170-174

Kim C, Iseki H, Herbas MS, Yokoyama N, Suzuki H, Xuan X, Fujisaki K, Igarashi I (2007) Development of TaqMan-based real-time PCR assays for diagnostic detection of Babesia bovis and Babesia bigemina. Am J Trop Med Hyg 77:837-841

Kocan KM (1995) Targeting ticks for control of selected hemoparasitic diseases of cattle. Vet Parasitol 57:121-151

Koney EB, Dogbey O, Walker AR, Bell-Sakyi L (2004) Ehrlichia ruminantium seroprevalence in domestic ruminants in Ghana. II. Point prevalence survey. Vet Microbiol 103:183-193

Leeflang P (1977) Tick-borne diseases of domestic animals in northern Nigeria. I. Historical review, 1923-1969. Trop Anim Health Prod 9: $147-152$

Leeflang P, Llemobade AA (1977) Tick-borne diseases of domestic animals in northern Nigeria. II. Research summary, 1966 to 1976. Trop Anim Health Prod 9:211-218

Lorusso V, Wijnveld M, Majekodunmi AO, Dongkum C, Fajinmi A, Dogo AG, Thrusfield M, Mugenyi A, Vaumourin E, Igweh AC, Jongejan F, Welburn SC, Picozzi K (2016) Tick-borne pathogens of zoonotic and veterinary importance in Nigerian cattle. Parasit Vectors 9(217):217. https://doi.org/10.1186/s13071-016-1504-7

Martins TM, Pedro OC, Caldeira RA, Rosario VED, Neves L, Domingos A (2008) Detection of bovine babesiosis in Mozambique by a novel seminested hot-start PCR method. Vet Parasitol 153:225-230

Ogo NI, Fernandez De Mera IG, Galindo RC, Okubanjo OO, Inuwa HM, Agbede RIS, Torina A, Alongi A, Vicente J, Gortazar C, Fuente JDL (2012) Molecular identification of tick-borne pathogens in Nigerian ticks. Vet Parasitol 187:572-577

Ogunsusi RA (1989) Field application \& evaluation of diagnostic and control methods of ticks \& tick-borne diseases of cattle in Nigeria. Final technical report of the EEC-Sponsored ABU/RUU project. Project No. 5106.53.41.001 October, 1984-November, 1987. Ahmadu Bello University, Zaria

OIE (2009) Heartwater - cowdriosis. Aetiology epidemiology diagnosis prevention and control references. October 2009 ed. http://www.oie. int/fileadmin/Home/eng/Animal_Health_in the World/docs/pdf/ Disease cards/HEARTWATER FINAL.pdf: World Organisation for Animal Health

OIE (2013) Bovine babesiosis. Aetiology epidemiology diagnosis prevention and control references. 2013 ed. https://www.oie.int/ fileadmin/Home/eng/Animal_Health in the World/docs/pdf/ Disease_cards/BOVINE_BABESIOSIS.pdf: World Organisation for Animal Health. Accessed Jan 152019

Olabode HOK, Jegede OC, Ajagbonna OP, Adah BMJ, Obafemi FA (2014) Evaluation of hemoparasites in trade cattle slaughtered in Jos abattoir, Plateau state-Nigeria. Int J Livest Res 4:113-120

Papadopoulos B, Brossard M, Perie NM (1996) Piroplasms of domestic animals in the Macedonia region of Greece; 2. Piroplasms of cattle. Vet Parasitol 63:57-66 
Provost A, Bezuidenhout JD (1987) The historical background and global importance of heartwater. Onderstepoort J Vet Res 54:165-169

Purnell RE, Young ER, Brocklesby DW, Hendry DJ (1977) The haematology of experimentally-induced B divergens and $\mathrm{E}$ phagocytophila infections in splenectomised calves. Vet Rec 100:4-6

Savadye DT, Kelly PJ, Mahan SM (1998) Evidence to show that an agent that cross-reacts serologically with Cowdria ruminantium in Zimbabwe is transmitted by ticks. Exp Appl Acarol 22:111-122

Steyn HC, Pretorius A, Mccrindle CME, Steinmann CML, Kleef MV (2008) A quantitative real-time PCR assay for Ehrlichia ruminantium using pCS20. Vet Microbiol 131:258-265
Susan, A. \& Asa, M (1998) The Merck veterinary manual, Whitehouse Station, N.J. Merck \& Co., in cooperation with Merial Ltd.

Tay ST, Koh FX, Kho KL, Ong BL (2014) Molecular survey and sequence analysis of Anaplasma spp. in cattle and ticks in a Malaysian farm. Trop Biomed 31:769-776

Young AS, Groocock CM, Kariuki DP (1988) Integrated control of ticks and tick-borne diseases of cattle in Africa. Parasitology 96:403-432

Zintl A, Mulcahy G, Skerrett HE, Taylor SM, Gray JS (2003) Babesia divergens, a bovine blood parasite of veterinary and zoonotic importance. Clin Microbiol Rev 16:622-636 